Témoigner Témoigner. Entre histoire et mémoire

Getuigen Revue pluridisciplinaire de la Fondation Auschwitz

$118 \mid 2014$

Au nom des victimes. Dictature et terreur d'État en Argentine, Chili et Uruguay

\title{
Catastrophe vs. Tragedy
}

Interview with Annette Becker, historian of the Great War and of extreme violence in the $20^{\text {th }}$ century

Tragédie vs catastrophe. Entretien avec Annette Becker, historienne de la Grande Guerre et des violences extrêmes du XX ${ }^{e o}$ siècle

Tragedie vs. Catastrofe. Interview met Annette Becker, historica en specialiste op het gebied van de Grote Oorlog en het extreme geweld van de $20^{e}$ eeuw

\section{Annette Becker}

\section{CpenEdition \\ Journals}

\section{Electronic version}

URL: http://journals.openedition.org/temoigner/1094

DOI: 10.4000/temoigner.1094

ISSN: 2506-6390

Publisher:

Éditions du Centre d'études et de documentation Mémoire d'Auschwitz, Éditions Kimé

Printed version

Date of publication: 1 October 2014

Number of pages: $42-47$

ISBN: 978-2-84174-674-3

ISSN: 2031-4183

Electronic reference

Annette Becker, "Catastrophe vs. Tragedy », Témoigner. Entre histoire et mémoire [Online], 118 | 2014, Online since 01 October 2015, connection on 23 October 2020. URL : http://journals.openedition.org/ temoigner/1094; DOI : https://doi.org/10.4000/temoigner.1094 


\section{Catastrophe vs. tragedy}

Interview with Annette Becker, historian of the Great War and of extreme violence in the $20^{\text {th }}$ century.

Let's begin by discussing you background. How did Annett Becker become an historian of the Great war, wh a very specific focus her colleagues?

Annette Becker: In fact, I'm an historian of the Great War by thesis in history on the American religious awaken Aneran religious awakenings of the lways been interen, faith. I' always been interested not in charch institus, believe when we butieve, how we believe when we believe, how we ( co to speak, war mencounts while so to speak, war memorials while arking a a conlission from an archaeology publisher. I was living in New York at the time, and I got a phone call: "Wed memils." I was a bit (a) I'd always but a entirely, since Ver always had a passion for war me had really taken an interestin

(1) Professor at Paris West Nanterre
La Defense, HAR EA 4414, IUF. Author of Biographie de guerre d'Apollinaire
(Paris: Tallandier, 2009, republished in 2014) (Paris: Tallandier, 2009, republished in 2014)
Les cicatrices rouges, 1914-1918, France et Belgique occupées (Paris: Fayard, 2010),
Yoir la Grande Guerre, un autre récit, 1914-2014 Voirla Grande Guerre, un autse
(Paris: Armand-Colin, 2014). hem. Antoine Prost had of course iscussed them briefly in his the dis on veterans. He had noticed a and the war memorial, buthe sawit (a) vore from a social history point of in the tried to locate every thing in thibutes to the Reprise say so. tributes to the Republic, paciser or its opposite-but he didn't itself everywhere. That's what tried to highlight in that book, tried to highlight in that book, which changed my acadenic ins. Not that I hadn't worked on iol Not that I hadn't worked on violence before, because religious vis was extrenty prevalent, as was the case with my PresbyteHan ministers fighting so terribly in the 18 century. But with war lence of war, which we the violence of war, which was obviously something quite different. The ing with Jay Winter after he read g with Jay Winter after he read meook. He then asked me to join the tean for the nus as being developed. the Muse

He Great the tean a

However, the team already Jacluded a man named JeanJacques Becker - my father - and with him when I had gone all the

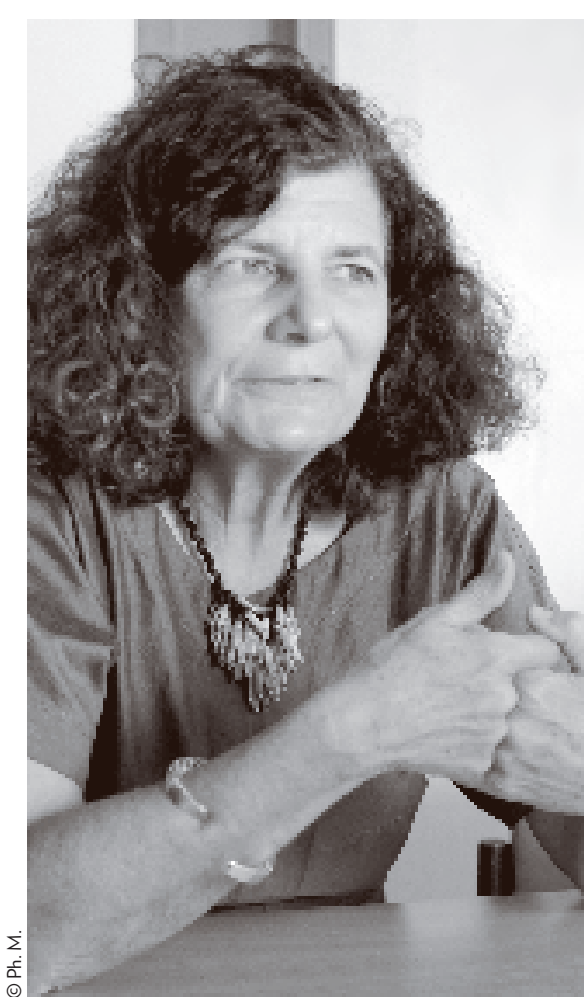

My first real book was entitled War and Faith, From Death to Memorial. ${ }^{2}$ Finally, faith moved to the background while death and memory became my priorities. The two other intellectuals who really influenced me were Étien d Maurice Agulhon, who died last May

So working with a team of historians of such calibre was decisive. Annette Becker: What that First World War circle gave me was mmense international openness. You cannot understand a world the magnifying glass of the fifty the magnitying glass of the fifty kilometres between Soissons, Whence my difficulties with som. of my colleagues in France. If of my colleagues in France. If we ave such deep "masents of the First World War", it's not much due to what they ,its no much due to what they say against our apro- its so Franco-French, and they only understand France through the prism of French politics - those politics That warwas a multi-pos politics. Thatwar was a multi-polar rively, thoughit elgian Belgian territory, and on the other Russian territory, in and in the Ottom, in the Balkon, and in the Ottoman Empire, it had pecine belligerents. Seekinects of the belligerents. Seeking to understand it from only one side comes down to understanding nothing. The representation of dot done from the French side, as if we on both sides, indoed on four, or five. We need for instance

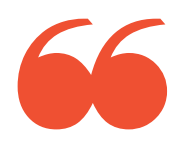

Frankly, the debate about consent and coercion is completely outdated, ridiculous.

It originates in

a very French way

of seeing things.

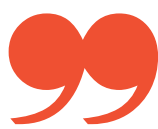

o understand why the Australian circled the globe to come fight here when there was no one makin hem do it; there wasn't a police

Franty, the dustralian!

Trankly, the debate about pletely outdaed, idis cons. prigin out in a ve ridiculous. It r seeing things. The experience we embar the ago when we all twenty years to was synthesized in Retrouter guerre ${ }^{3}$ was just th Retrouver guw by weingon the wester to and byving mone the enchor ish historiography ish historiography, we could get to phert a phenomenon that the English fully than the French mondial. We fully than the French moritial. We eed to talk about globality while and other differences, of cours, and other differences, of course,
Following the course of the body of your work, we see that a time comes when you turn toward civilian populations.

Becker: Yes, I took an interest in those who were marginal: prisoners, occupied popuand mong them, women, of course, a way, we kn "too nuch" into those who were so Ilooked in those who were combatting light of cilin, foc "for on plight of civilians, the "forgotten he title of or ${ }^{2}$ relly were forgotten That They really were forgotten. That led me a few detours I came to the Armefew detours I came to the Armenians, to the specificity of, shall we the the rejection of the other, of the way we eliminate the other during it The Armenime other

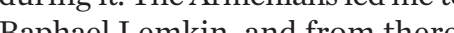
Raphael Lemkin, and from there

The idea is that the First World War is a military front that canno be understood in isolation from ane the ther the a question of the home front, but like laboratories poisonts thare fter that war, central fronts for the rest of the central fronts for

(2) Becker, Annette, La guerre et la foi, de la mort à la mém

(3) Audoin-Rouzeau, Stéphane \& Annette Great War, New York: Hill \& Wang, 2002.) (4) Becker, Annette, Oubliés de la Grande
Guerre : Humanitaire et culture de guerre. opulations occupées, déportés civils, prisonniers War; the humanitarian and the war culture, the occupied population, the deported civilians, 


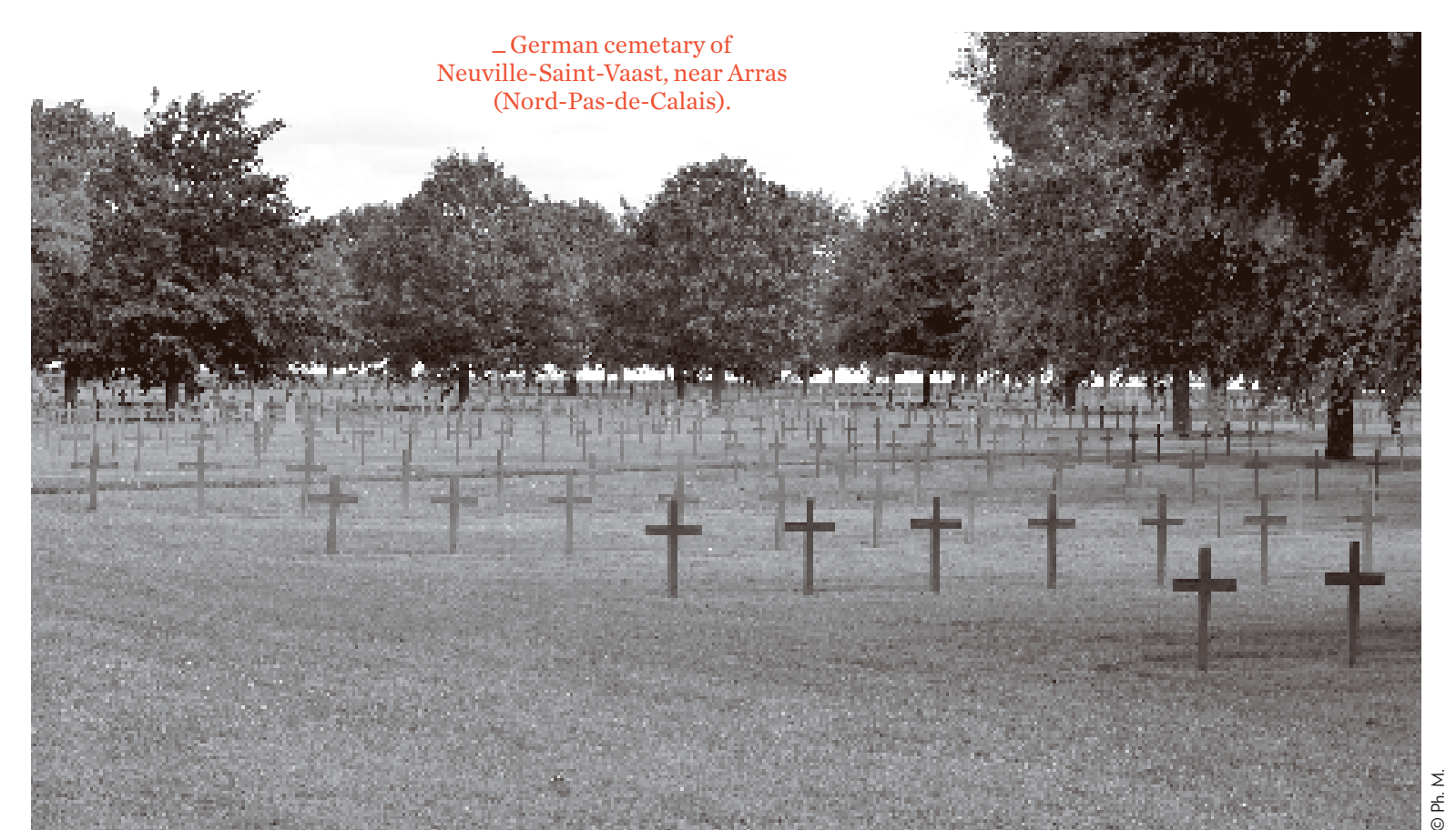

œ. pations front, the prisoners front, the hospitals front, the massacres ront, the voluntary labour deportations front, and finally, the extertarting in 1943, genocide. Gearthe 1943 , genocide. The Great Wations of situations. All we need to do is und how we can create and he can create meaning from that.

We are about to enter an intensely commemorative period. Are we sufficiently aware of what is

Annette Becker: What seems interesting to me in the Cente"poilus", the French inf put the poilus , the French infantrymen, ront and centre, we realized that the soldiers from the society, as

if they were holding their breath 政 didnes. We reallzed that if we on the bome frit society, thine on the home front, those behind the lines, if we didn't work on all the people whose lives were conWorld War, we could not underWorld War, we could not underThe 20 century.

There have been advances i understanding in which the Belthe were very involved. about for forced labour, the massive use for forced labour, the massive use World Waranse meaning World War sense, meaning internwhat they would becent from to they would becone. Even so, taking Belgians, Frenchmen, portingsians hostage and transporting then, sonetines very far camps behind barbed wire and watchtowers, that's not the Great War we're accut's not the Great ing I see so much in com inagith the Second World War thon partly forget the soldiers, the cans, the gas.

Civilians, that meanseveryone. All over the world. I'm thinking of the Australians of German origin who were locked up for four years. They were denaturalized at the start of the Fist Word War because they could have taken up I'm certain that for the CounteIn certain that, for the Centeextent of the phenomen. awareness is positive, and proawareness is positive, and produces meaning, whereas at first con afraid it would be a bit like the centenaryoftherrench Revolution:

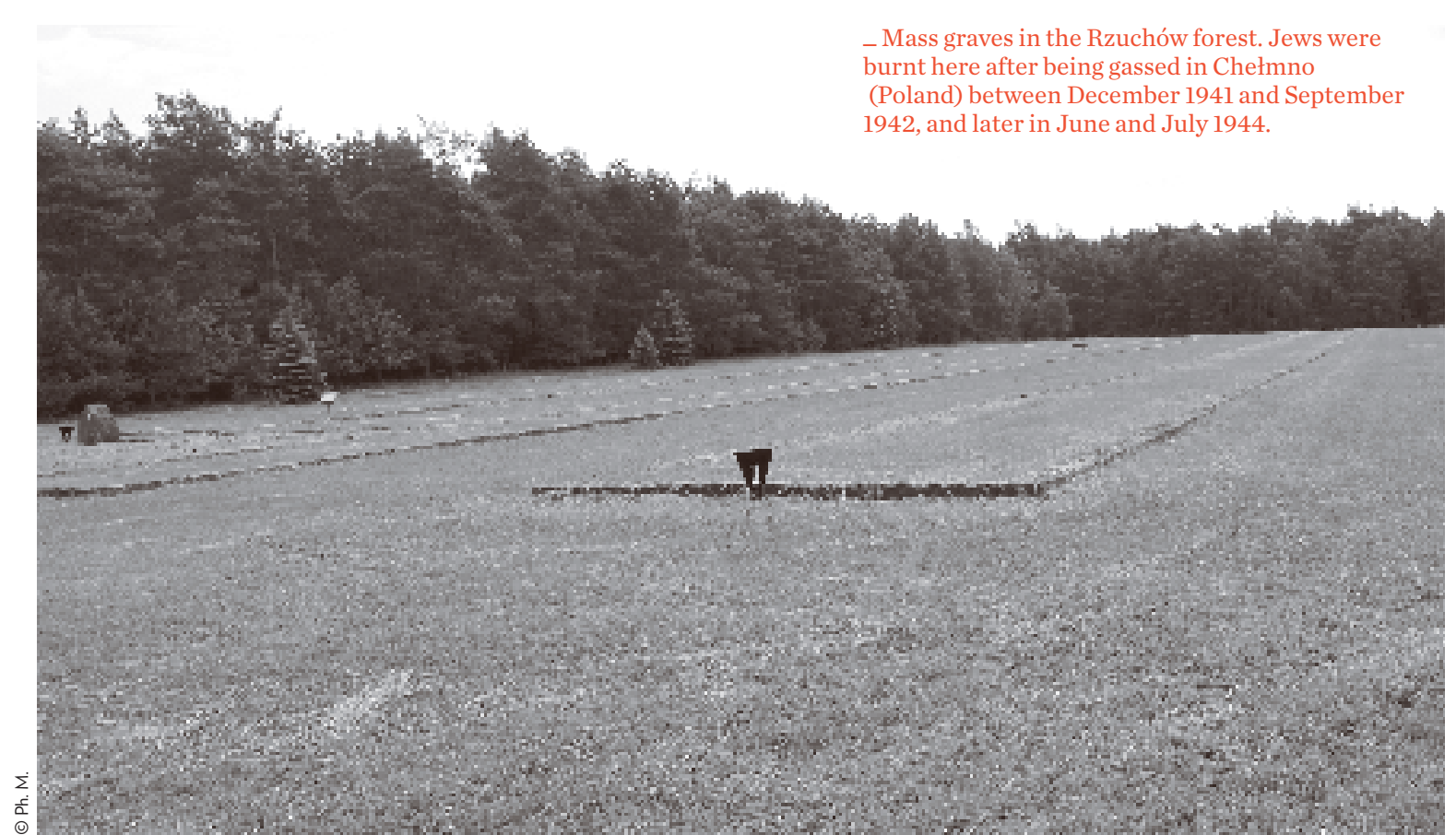

and an epistemological retreat from new historiography. I'm a

Though we tend to disparage the commemorations, does that indicate commorations, does that indicate toyounonethess that hey can also that that is, be productive of knowledge and not only of doxa?

Annette Becker: I think we achieved something positive. he Ceated advisory boards for the Centenary, alongside the big pig political events are that big political events are the ones the and that will prevail. I'm thinking, Hollande will do on 11 Novero Hollande will do on 11 Novemmis a dentrat In the Pas-de-Calais, near the
Lorette cemetery, he will unveil an enornous ring on which will be engraved the nanes of allorthe de-Canis re dis is the Pasbeing built, an. It is curenty Jeing built, an absolutely huge job. A regional efrort to address a the dead together in alphabetical the dead together, in alphabetical the fat The they kney fought the hustralian or Welsh al , Austrian, Australian, or Welsh. allorthatwil disappear in that ring thing where weath of thathers in the mass marked the beginning of the $20^{\text {th }}$ cercen " November 2014" that was sold to Francois Hollande by the socialist politicians of the Necialist policians of the Nord-Pas-deDaniel Perche and especially by of the region, having found historians who are convinced of the correctness of the mission and do not understand that it rests on the most irenic possible vision: They all the the same death together,

Should we see a sort of assimilation of those deaths to the victim lation of hise deaths the victins influence of Holocist there, Annette Becken Absolutely, that's exactly what's happening A lot so intellectuals have noted and underinedit teonlydeathwe The model has imposed itself.

I would say that the model has for very complex reasons that we won't objectivise during this able discuss is deathin the Shorh. 
œ. meeting - imposed itself, or been imposed, through a combination of speeches and positionings, in a very

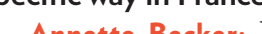

Annette Becker: Which completely negates the specificity of phe (hin to UNCO and the listing of the

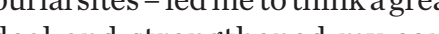
eal and strengthened ny convith Jay Winter becase he used With Jay to the Fist World War, a the rist Wonld War, and I geed wh that. In my opinion, we shot ring tragedy, catas its the sane thing. tragedy, catastrophe. But it inn'tat all. In a tragedy, we are equad melation to each other. That was equ qual in the differe way or being. equal while different. Whereas in a catastrophe, as with the Shoah, who kill and whose who are killed.

Conversely, we fight for the Shoah not to be discussed as a tragedy.

Annette Becker: Absolutely, the Shoah isn't a tragedy, it's mblein atragedy Jay Wintercous o the use the tern catstrophecause of the hor der.Where therewas mass murduring the Great War, it was dung dur the Armenian catastrophe, or the internal displacement of Jews (an the Russian frots Ap ort frin) on the Russian front. Apart from clese and it should abserelo visible in commemoration for very simple reason: what did we do during the First World War?
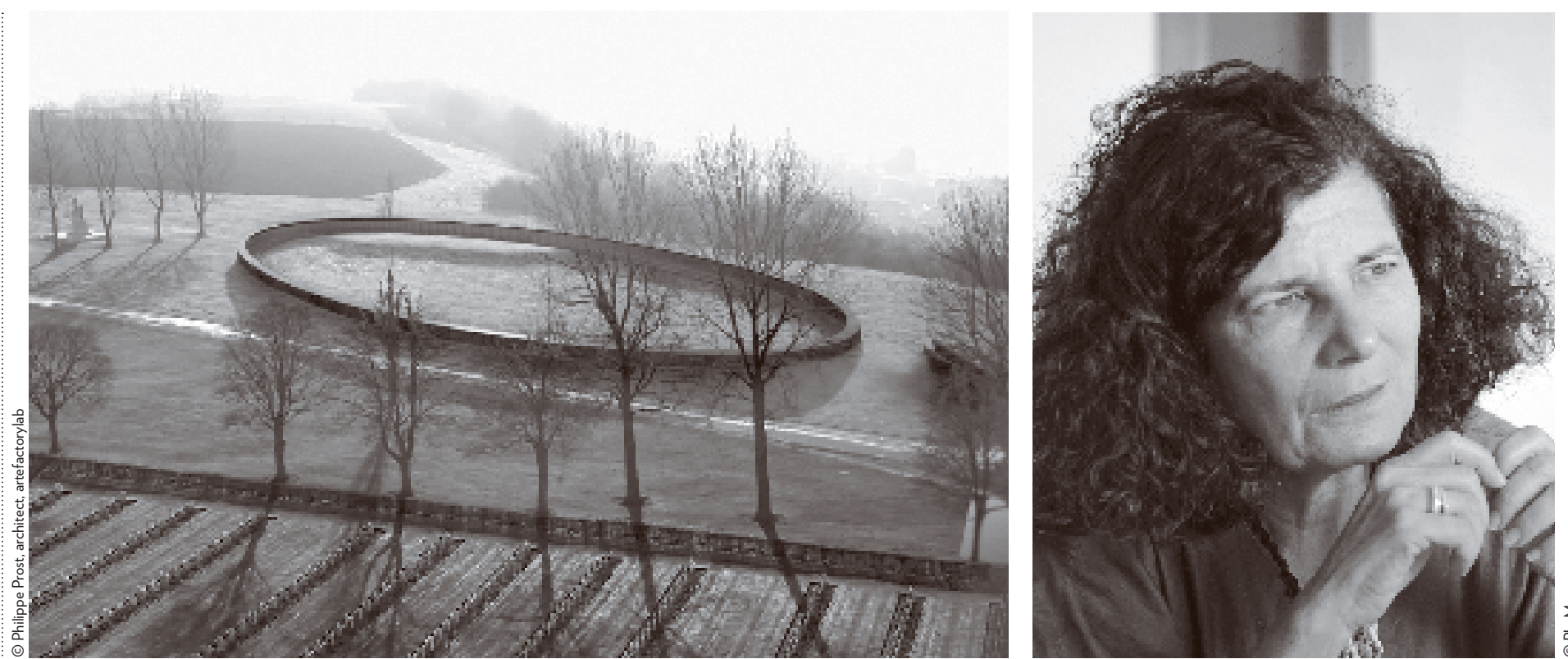

We tried everywhere, on every We titi, in extremely difficult con-

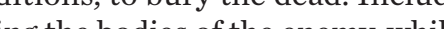
ing the bodies of the eneny, while the war was ongoing, and including dead prisoners. The respect see with the war that is what we towns, but also in the soldies former workpla in the soldiers he Bibliothè wa tions, Louve mueque Nationale, the The war grave, tainstations, etc. where, to parishes wited everyials in parishes with menoches churches, to synagogues, etc. We ring genocide, with whers during genocide, with mass murto hide the traces. That is a so the chathe that death f the FirstWod. War - and in way they fall with War-andin that py
Lorette commemorative ring

(eomputer generated image), on which
will be engraved the names of 600,000 soldiers of all nationalities dead in

1914 and 1918

during the Civil War - respect for the soldier was extended to the dignity of the tomb, which we find on bothsides of the belligerents. In a catastrophe, there is no reason, not a single one; you can think of everyson are all wrong, allalse, soyou do not You try to destroy every trem. You try to destroy every trace of ow they of death itself.

Precisely. Those historians, doing their utmost to denounce the theory of consent, arguing that all soldiers were pushed to slaughter, despite themselves, end up condoning those cally, to grant dignity to the victims they invoke the massacre model, which actually removes all dignity from the victims, so they end up ines. Foold, in the end, by the selves. Fooled, in the end, by the generalization of the universalized codel of mass murder, of the geno-

Annette Becker : Absolutely. They dise act, denied dignity. Whereas during the Great War, it was the opposite. If people militiry centeries and go to their beauty - in particuse their beauty - in particular the beauty of the German military ceneteries hat are extremelywelplanned to be seen as heroes garway) - thatindicates rerrible and industrial that terrible and industrial that war was, an element of respect for the do not find in genocide. And that

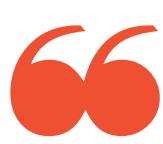

During genocide, with mass murder: no graves. Everything is done to hide the traces. That is also the catastrophe. All tangible signs of death are erased.

their credulity at the current doxa about mass murders. Nonetheless, with the advisory boards, there is a knowledge-producing momentum a

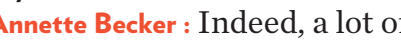
istorians around the world have vidual, aoks, collective and indipublis we of we publish. We is too rech is very serious po much. There taking place. I proratory work taking place. Important syntheses are organized. The problem is th Idon'the The probutis con't know how all of that is going keep abreast of it all Itis interting to see how researchers in the Anglo-Saxon countries are Allyvery interested in are ulations, including in thial popconions, including in the French colonies, while the French are just about everywhere around the just about everywhere around the people are taking the opportunity to reflect on the post certuThat's very positive. Beyond the That's very positive. Beyond the trying to think ditions, oc sacres, etc. In contrast, the off. sacres, etc. In contrast, the official on 1914-1918. I wonder what the on 1914-1918. I wonder what the will get pretty fed up. And we've will get pretty fed up. And we've $\begin{array}{l:c}\begin{array}{l}\text { was also incredibly strange. You } \\ \text { could be in the same place for three } \\ \text { weeks and nothing would happen. } \\ \text { You'd get bored. That aspect is still }\end{array} & \begin{array}{r}\text { still got four more years of ity too much. I It's } \\ \text { Interview conducted by Luba Jurgenson } \\ \text { and Philippe Mesnard on } 5 \text { June } 2014\end{array}\end{array}$

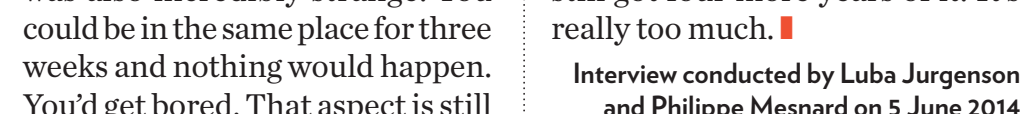
aspect is still There is a political deviation
and an illusion among certain historians who have been taken in, so to speak, by their noble sentiments and 